\title{
Perfecting Good Character Through the Approach of Prophet Muhammed in American Islamic Schools
}

\author{
Abdurrahman Toyese Adesokan \\ Department of Islamic History and Civilization \\ Academy of Islamic Studies, University of Malaya, 50603 Kuala Lumpur, Malaysia. \\ Toyese2000@yahoo.com \\ Abdullah Yusof \\ Department of Islamic History and Civilization \\ Academy of Islamic Studies, University of Malaya, 50603 Kuala Lumpur, Malaysia. \\ abdy@um.edu.my \\ Aizan Ali @ Mat Zin \\ Department of Islamic History and Civilization \\ Academy of Islamic Studies, University of Malaya, 50603 Kuala Lumpur, Malaysia. \\ aizan@um.edu.my
}

DOI: https://doi.org/10.22452/usuluddin.vol49no1.7

\begin{abstract}
Islamic theory of moral is in congruent with the Universal theory of moral. Noble characters and morals are the most essential path of Prophet Muhammed as he said "I was not sent except to perfect moral characters"1. This work will examine the effects of Islamic morals in propagating Islam in America to the level of winning the souls of American leaders including their presidents, that are canvassing for Islam as an acceptable peaceful religion in the West. The article will be supported through the research methodology of qualitative and the review of series of literatures that secured the credibility and the integrities that benefited Islam in the West. Moreover, moral character encourages the appreciation that is consider as a motivation for better performance, which American Muslims enjoy.
\end{abstract}

Key words: Moral character, Values, Western Values, Interest

\section{Introduction}

1 Rafik I Beekun, "Character Centered Leadership: Muhammad (P) as an Ethical Role Model for CEOs," Journal of Management Development 31, no. 10 (2012): 1003-1020. 
Islamic religion teachings, its philosophy and etiquettes are the noble character that prophet Muhammed was sent to actualize ${ }^{2}$ as he said: "I was surely sent to practicalize the noble character" إنما" بعثت لأتم مكارم الأخلاق، Understandably, individual behaviour and performance has attracted a great deal of attention by the watchers, the behaviours include pro-social behaviour "extra-role, behaviour" and organizational behaviour. All these behaviours are controlled with the factor which is the Taqwa (piety) that governs all the believers' actions.

It is well clear that Islam has no geographical boundaries that separate the Muslims, nor the factors that determine how strong, people are in faith or in their closeness to Allah except their Iman (faith). Their schools of taught are varies from one Muslim country to another but they are all bounded together with one rope which is the faith in (Lä ilahā illā Allāh wa Annā Muhammad Rasül Allāh) meaning, there is no deity worthy of worship except Allah and that Muhammad is His Messenger.

\section{Taqwa (Piety) A Value Required at All Time}

Bye and large all these behaviours will surely contribute to the performance of each employee at any company where they work, and it would at the end determine the success of the companies even though many observers do not pay attention to this when assessing employee's performance. ${ }^{3}$

Taqwa (piety) is an example of the values, however, both individual and groups will strive to achieve it with the goal to arrive at the pleasure of Allah that will earn them the paradise and the love of the people around such as the employers and the coemployees. That Taqwa ${ }^{4}$ (piety) is a value that non-Muslims also cherished in the life of the Believers.

2 Syed Jawad and Beverly Dawn Metcalfe, "Guest Editors' Introduction: In Pursuit of Islamic Akhlaq of Business and Development," Journal of Business Ethics 129, no. 4 (2015): 763-767.

3 Syed Jawad and Beverly Dawn Metcalfe, "Guest Editors' Introduction: In Pursuit of Islamic Akhlaq of Business and Development," 763-767.

4 Duygu Turker, "Islamic Roots of Corporate Social Responsibility," Cultural Roots of Sustainable Management, Springer 2016. 133-144. 


\section{Ihsan- Goodness and perfection}

Prophet Muhammed made it clear that, it is a highest level for dissemination of spiritual and social responsibilities towards Allah and to provide necessary welfare to stakeholders of any segment of the society. However, it is the highest level of perfection which is the excellence in faith. It is the level of being asserted of the true spirituality and to believe in God almighty without the slightest speck of doubt (Halaqa).

Ihsan is a value in Muslims character that only the Muslims can feel its sweetness in their life when they process it. It is a power that is diverting the attention of non-Muslims towards making the inquisitors the reasons why Muslims are doing what they are doing and their belief that their religion is so strong to the level that they can do whatever comes to their mind that Allah or his messenger ask them to do, to the highest-level of perfection which is the Ihsan and Prophet Mohamed, gave perfect answer to angel Jibril when he asked him about Ihsan and he said: "To worship Allah as if you see him and if you cannot achieve this state of devotion, then you must consider that He is looking at you."

$$
\text { أن تعبد الله كأنك تراه و إن لم تكن تراه فإنه يراكْ }
$$

Human reflection of his or her common morality towards God almighty and individuals that comes his way are based on the Islamic rules and guidance that are embedded in the system. Muslims should know that all the rules must be kept and any violations to any of the rules without adequate justification are immoral actions (Gert). Moreover, in order, for the society to be at peace with Allah the creator and others, this Ihsan must be practiced at all levels of human endeavours as a strategic way of providing a comprehensive view of Islam and Muslims to cultivate peace, promote universal values and dialogue among civilized people. 6

5 Recepn Kaymakcan, "Religious Education Culture in Modern Turkey," in International Handbook of the Religious, Moral and Spiritual Dimensions in Education (Springer, 2009): 449-460.

6 Hamza Yusuf, "The Concept of Ihsan," website Islamicity, www.islamicity.org/5761/the-concept-of-ihsan-by-hamza-yusuf/, 2014. Islamic City .org. 06/12/2018 2018. 


\section{Forgiveness}

Forgiveness expression should be more effective in making the world and people's surrounding to be peaceful and better place to be. True forgiveness is more spiritual than been scientific and this is the reason why scientist research on forgiveness has never been relevant ${ }^{7}$ because it lacks the religious tenets that can explain why and how it happens whenever it happens. Forgiveness in Islam is real as been learnt through the life history of Prophet Muhammad ${ }^{8}$.

A Muslim family made a record in the city of Lexington Kentucky, when a man that was about to sentenced to death was forgiven by the family. Emerging the man that, his mind has been occupied with sorrow, clemency, sin, evil, guilt and ways for expiation to be forgiven. How can it be explained, if one that is expecting the worst to happen to him secured freedom through the clemency and forgiveness of the father of the victim of murder.

The Muslim father made the history in America by hugging the man that was convicted over the murder of his son and forgave him in Lexington Kentucky, saying that he did that in the spirit of Islam. He said: "Islam teaches that God will not be able to forgive someone unless the person they wronged has first done so." ${ }^{\circ}$ His son, the young man Salahuddin Jitmoud, 22-years-old was murdered when delivering pizza by Trey Relford 31, who was later sentenced to 31 years in prison instead of death penalty. Trey's mother requested for Mr. Salauddin email address, telling him that she wanted to learn more about Islam.

\section{Islamic Schools and Morals}

Morals are keys to success in school ${ }^{10}$. This should be fundamental in the school system that all the students must go by, it will paint them with the picture of the right people in the society.

7 Kaymakcan, Recep, "Religious Education Culture in Modern Turkey," in International Handbook of the Religious, Moral and Spiritual Dimensions in Education, 449-460.

8 Fawziah K. Al-Ammar, Ismaiel H Ahmed, and Mohamad Sahari Nordin. "Moral Character of Muslim Personality: Scale Validation," Journal of Education and Practice 3, no. 16 (2012): 118-28.

9 Rosemary C. Salomone, Visions of Schooling: Conscience, Community, and Common Education (N.p.: Yale University Press, 2002).

10 Aynur Pala, "The Need for Character Education," International Journal of Social Sciences and Humanity Studies 3, no. 2 (2011): 23-32. 
Darul Arqam school is an exemplary school in Houston Texas of U.S.A. Its authority believed that children, and their parents' interests must be considered as the priority in their planning. The board chairman for the school in Houston mentioned that the school is working with a committee that oversees making sure that, their programs must be geared toward the interests of the students. This will give the school the opportunity to arrive at the best result. Children generally, according to Rosemary C Salomone in her book called "Visions of schooling" said that "children generally revolve around two interrelated issues, first issue addresses the distribution of decisions power among the child, the parent, and the state, while the second involves interest balancing among the child, the parent, and either a particular segment of society or society at large."

\section{Islamic Education and moral at Darul Arqam Schools}

Muslim schools like Darul Arqam are trying their possible best in giving their students the best foundation in life. It classifies their religion and the beliefs in almighty God, the creator, the sustainer, protector and provider. The beliefs and its effects are the best indicators of the decisions made by the individuals in their lives and it will sustain and guide them in their life. ${ }^{11}$

Darul Arqam always make sure that their teachers are those of the best practical implication of the moral approach of Prophet Muhammed in life. This will reflect in their behaviours in the classroom and determine their perception and judgement on issues. ${ }^{12}$ It will also help the school to achieve the goal of producing exemplars of virtues and behaviours ${ }^{13}$. The teachers' candid will also be reflected in his or her professional preparation

11 Albert Bandura, "Social Foundations of Thought and Action," The health Psychology Reader (2002): 94-106.

12 M Frank Pajares, “Teachers' Beliefs and Educational Research: Cleaning up a Messy Construct," Review of Educational Research 62, no. 3 (1992): 30732.

13 Wafa El Garah et al., "Character Centered Leadership: Muhammad (P) as an Ethical Role Model for CEOs," Journal of Management Development (2012). 
and teaching practices ${ }^{14}$ The target is to prepare the students for this world and the hereafter. Religious private schools do not enjoy any financial support from the government because the schools are faith-based schools like the Christians and Jews that are $100 \%$ founded and controlled by the religious groups ${ }^{15}$. Some parents preferred to spend their resources and energy to enrich their children with perfect education, since the law of the land gives parents the right to control their children's education and upbringing ${ }^{16}$.

\section{Parents Role and the Moral Education}

Many parents realized the importance of Islamic schools in their environment after having knowledge about what their children are exposed to in the secularized government schools. In the early 1990s, school systems across the United States of America started distributing free condoms to secondary school students with the intention of saving them from falling victims of the AIDS virus that are rampant among the adolescents today ${ }^{17}$. The environment has been polluted with the idea of using condoms among the children of young adults especially when their parents have no control over their choices to take it or not to take it. Government in some States like New York, Falmouth, Massachusetts are forcing the parents to allow their children to use condoms.

Mothers are the first teachers of the house that guides the children from the infants and bring them up morally. Muslim mothers in the western world asks herself daily how to raise her children based on Islamic values in an environment that is totally different from their Islamic society. The environment where secularism is the order of the day and socialism is the running

14 Kathryn F Cochran, James A DeRuiter, and Richard A King. "Pedagogical Content Knowing: An Integrative Model for Teacher Preparation," Journal of Teacher Education 44, no. 4 (1993): 263-272.

15 Patrick J McEwan and Martin Carnoy, "The Effectiveness and Efficiency of Private Schools in Chile's Voucher System," Educational Evaluation and Policy Analysis 22, no. 3 (2000): 213-239.

16 Rosemary C. Salomone, Visions of Schooling: Conscience, Community, and Common Education.

17 Jacqueline E Darroch, David J Landry and Susheela Singh, "Changing Emphases in Sexuality Education in Us Public Secondary Schools, 19881999," Family Planning Perspectives (2000): 204-11. 
system in the life of the masses, where they are worshipping the wealth and the selfishness. This is a lifestyle that is mounting measures on the parents and the children. Creating worry and hopelessness for the parents that will be asking what the solution is.

It must be agreed upon that Islamic training is the only solution for the parents that are willing to raise their children as Muslims. The responsibility of taking care of the children starts with the infancy stages when the child will be able to identify his mom and dad by hearing their voices. Since then, they should be given instructions and it was ordained that early instruction should exert a decisive influence on character, and that during this important period of existence, children should be subject to the charge of their parents. It is the parents' responsibility especially the mother to know precisely what the school is teaching their children, morals and essential values must be included and both the parents must be vigilant of watching all other extra curriculum activities that has nothing to do with what is expected of them at certain age. This is the reason why the role of the parents in the raising and rearing of their children is of inestimable vale and is deserving of praise and protection by all levels of the government. $^{18}$

There was stability of moral education in America until it eroded dramatically, and the US began to undergo a series of political, economic, social and demographic transformations. The transformations brought enormous new opportunities to the states. This was after America has been taking moderate position on moral education. Some changes transferred the American life from what it used to be. The American government introduced context of sex and family life into educational program in the 1970s and 1980s. It leads to misunderstanding between the government and some parents ${ }^{19}$.

ISGH has the track for appointing the right people into the right department in the school system. Muslims are making

18 Barbara Bennett Woodhouse, "A Public Role in the Private Family: The Parental Rights and Responsibilities Act and the Politics of Child Protection and Education," Ohio St. LJ 57 (1996): 393.

19 R. C. Salomone, Visions of Schooling: Conscience, Community, and Common Education. 
strenuous efforts to make sure that the Islamic school is retained even if they should spend their personal money to sustain it.

Darul Arqam schools are more into religious and moral values. With this, the concept of religious exemption from educational programs or practice was introduced ${ }^{20}$. School districts during the period between the late 70 s and early 80 s, introduced the sex and family educational program into school program across the country. It was even supported with state mandate.

Majority of the state law made the new courses that has to do with sex related issues optional for students and their parents were given the right to request that their children are exempted from participating, generally on religious grounds. ${ }^{21}$ This was the court decision on this issue, after they were all ascertained that the child is not the mere creature of the state; those who nurture him and direct his destiny have the right to compel him or her with the high duty, to recognize and prepare him for additional obligation toward almighty Allah. ${ }^{22}$

\section{Islamic Schools Working on Eradication of Commotion Among the Faiths-Based Groups}

Islamic schools always find a way to neutralize all the teachings of Islam that are against the teachings of the Christianity or Jewish traditions in a friendly manner through dialogue that Islam recommends as Allah says: "And argue not with the people of the Scripture (Jews and Christians), unless it be in (a way) that is better (with good words and in good manner, inviting them to Islamic Monotheism with His Verses), except with such of them as do wrong, and say (to them): "We believe in that which has been revealed to us and revealed to you; our Ilah (God) and your Ilah (God) is One (i.e. Allah), and to Him we have submitted (as Muslims)." (Quran 29:46)

Among the Islamic tolerance that the Darul Arqam school is passing to the students is to accept and embrace Jesus Christ that

20 R. C. Salomone, Visions of Schooling: Conscience, Community, and Common Education.

21 Robert M. O'Neil, Classrooms in the Crossfire: The Rights and Interests of Students, Parents, Teachers, Administrators, Librarians, and the Community (N.p.: Indiana University Press, 1981).

22 Robert Louis Mizia, "Prejudice and Educational Choice: 75th Anniversary of Pierce V. Society of Sisters," Momentum 31, no.2 (2000): 17-19. 
majority of the children of Israel rejected. ${ }^{23}$ It must be stated exhaustingly that Islam's teachings regarding the personality of Jesus and his mother Mary built a cohesive relationship between the Muslims and the right mind of thinking Christians. All these togetherness in term of building cohesiveness among faith groups are in line with the calls of Islam for supportive cooperation on matters of morality, development and social justice. ${ }^{24}$

\section{Academic Achievement and the Mingling of Opposite Sexes}

Protection of the females from sexual harassment is a value that Darul Arqam schools promote within the school premises, when students are still moving around together in the same environment. Parents are always happy to see that their children are not allowed to engage in any premarital relationship that are un-Islamic, unlike the public schools where boys and girls are mingling freely, holding their hands, touching one another without any barrier, These are not possible because teachers and other staffs are gazing at their students all the time and they are also aware that they are in an Islamic environment.

The Islamic tenet of segregation between the opposite sex will be the normal life for the graduates of Darul Arqam school. Gender issues; particularly, the permissible level of mingling between males and females are the most fraught topic the Muslim students wrestle with whenever they organize events. ${ }^{25}$ Ladies hijabs should not steer them away from participating in any event. It should make them comfortable in their own skin and for them to master the delicate mix of the American and Muslim identities. ${ }^{26}$ As American young men, they should have an insatiable desire to feel confident and comfortable within their Islamic environment that gives adequate respect to genders related feeling. As Muslims with males and females should know that there are some Islamic standards of behavior.

23 Oddbjørn Leirvik, Images of Jesus Christ in Islam (N.p.: Bloomsbury Publishing, 2010).

24 Benaouda Bensaid and Salah Machouche, "Muslim Morality as Foundation for Social Harmony," Journal of Al-Tamaddun 14, no. 2 (2019).

25 Neil MacFarquhar, "For Muslim Students, a Debate on Inclusion," New York Times 21 (2008).

26 Maria M Ebrahimji and Zahra T Suratwala, "I Speak for Myself: American Women on Being Muslim," Ashland, OR: White Cloud Press (2011). 
Co-education should be seen avoided if possible because it is not them mainstream of schooling for boys and girls. ${ }^{27}$ School authority must design a perfect system to educate boys and girls together in the same class. The perfect way to separate them side by side where they all will study together as this will help both groups assimilate more. The point is that mingling and mixing of males and females that are not couples and not members of the same family is prohibited in Islam. Prophet Muhammad said:

Allah (SWT) says: "Tell the believing men to lower their gaze... and tell the believing women to lower their gaze". (Q24:29-30).

\section{Opinion Leaders and the Government should be Responsible for Community Upliftment}

A society cannot be developed securely and morally when its promising youths are on the streets selling drugs and engaging in illicit sexual intercourse. When the youth do not have respect for the elders and parents. The changes should be introduced by the community leaders and the government before they expect Allah to make it possible. This has been confirmed by Allah in the Quran where it says: "Verily! Allah will not change the good condition of a people if they do not change their state of goodness themselves (by committing sins and by being ungrateful and disobedient to Allah). But when Allah wills a people's punishment, there can be no turning back of it, and they will find besides Him no protector." (Quran 13:11).

However, failing to correct wrongs may lead to many other defects because the outcome of not acting before a catastrophic event occurs can be extraordinary, "Those who cannot show that they have introduced all or most of the available "common" preventive measures will pay dearly if a serious incident occurs on their watch, whether or not the common preventive measures would have prevented the incident".

Community opinion leaders should be aware of ways and manners in correcting any misbehaviour with disciplinary actions. Changes can be made by getting tougher in dealing with disruptive behaviour and disciplinary alternatives that are necessary to curb

27 David Tyack and Elizabeth Hansot, "Learning Together: A History of Coeducation in American Public Schools," Russell Sage Foundation (1992). 
all the bad behaviours in the school system. A study said that, a school official in America in the 90s responded to a frightened constituency by demonstrating their firm commitment to cracking down on inappropriate behaviours. ${ }^{28}$

\section{Non-Muslims, Baptists, Catholic Christians and Politician, defending Islam}

A Baptist politician in Houston Texas of America is one of the famous politicians that is well known among the Muslims with his support and defend of the Muslims. He is the congressman, representing Texas, Mr. Al Green. $\mathrm{He}$ is originally from Christians ground parents. He sees Islam as a great religion that can be compared with Catholicism that was viewed for a long time as the paradigmatic anti-modern fundamentalist religion. While it served as the central focus of the enlightenment critique of religion.

Congressman $\mathrm{Al}$ Green went all the way to the congress on December 15, 2015 purposely to defend Islam and the Muslims that have been tagged as terrorists, he was given only 5 minutes to proof that Muslims are not terrorists and their religions one of the great religions of the world. He said:

"I stand here today in the well of the house, Mr. Speaker, to announce my solidarity for justice, my solidarity with the Muslim community for justice, because I understand what it is like to be a part of a community that is treated unjustly. I lived through segregation in the United States of America. I know what it is like to drink from filthy "coloured" water fountains, I know what injustice looks like. I have seen its face. I know what it smells like. I have been in waiting rooms where only Blacks could sit. They were for blacks only because other places for others. I don't want to see anything like that, like that is remotely similar - occur to someone else. I am standing here today here today in solidarity with the Muslim community because of the injustice that is being perpetrated against Islam. I am a Christian. My grandfather was a Christian minister. But I stand here to support Islam today, one of the great religions of the world. I do this, Mr.

28 Jeanne B Stinchcomb, Gordon Bazemore and Nancy Riestenberg, "Beyond Zero Tolerance: Restoring Justice in Secondary Schools," Youth Violence and Juvenile Justice 4, no. 2 (2006): 123-47. 
Speaker, because to demean Islam by adding the word terrorist with it is an injustice to the religion. I stand for justice, and I stand for justice for the Islamic faith" ${ }^{29}$

This is the man that I saw for the first time in Houston during an Islamic function and I thought that he was a Muslim because his enthusiastic about Islam and the Muslims. I discovered that he wasn't after the brief formal introduction. This is the man that some Americans are in doubt if he is a true American because of his support for the less privileged people.

It is an underlining principle of the prophet that there must be a healthy environment. A lovely atmosphere. A diverse society like that of Houston Texas requires the Muslims to continue propagating the Islamic social ethics and morality in the way of showcasing the commonalities in dealings in any cultural society $^{30}$.

\section{Conclusion}

This work proofs without equivocation, that practical implication of Prophet Muhammed's character and moral approach to life enhance Muslims in America the freedom of Living in the States by all standards without the fear of Oppression or suppression. The System that provides to its citizens and legal immigrants, security of life and prosperity irrespective of their status, religious inclination, ethnic background, and social orientation.

Both Muslim and Non-Muslim, says good things about Islam and the Muslims. Islamic Society of Greater Houston, the founder of Darur-Arqam schools maximizes the benefit of this goodwill to build the life foundation of their students on moral, excellence performance and high educational standard. Applying Dr. Ismail R. Al-Faruqi's ideology on; the need to transcend an apologetic or polemic approach to the study of comparative religious and to engage in what he regarded to be a more objective, scholarly study. ${ }^{31}$

29 Monet Clarke, "Race, Partisanship, and the Voting Rights Act (Vra): African-Americans in Texas from Reconstruction to the Republican Redistricting of 2004," Tex. J. on CL \& CR 10 (2004): 223.

30 Benaouda Bensaid, and Salah Machouche, "Muslim Morality as Foundation for Social Harmony," Journal of Al-Tamaddun 14, no. 2 (2019).

31 Yvonne Yazbeck Haddad, A Century of Islam in America (Washington, DC: American Institute for Islamic Affairs, 1986). 
This is the foundation that will specify the identification of higher principle which are to serve as the basis for the compares of various systems of meanings, of cultural patterns, of moralities, and of religions; the principles by reference to which the meanings of such systems and patterns may be understood, conceptualized, and systematized. Islamic schools happened to be the only solution to the immorality that have eaten deep into the fabric of society. The reality of Islam comes with answers to most of the questions that the society has been looking for a long time.

Islam is playing positive roles among the immigrants in smoothing and facilitating the adaptation process. ${ }^{32}$ Many indications show that the United States of American environment is far more favourable for immigrants than the Western Europe. It proofs that Islam is an American religion with its million members all over the states. ${ }^{33}$ Opportunities are given to Muslims to engage in many fields of wealth, economic driving to showcase Islam as a religion for the elite, with the survey that shows that majority of American Muslims are employed in technical, white collar and professional fields, information technology, corporate management, medicine, and education. ${ }^{34}$ It creates room of second thoughts for anti-Islam and the Muslims to exercise patience in labelling Muslims with bad names. It allows the westerners to differentiate between the secularism, Islamic modernism and radical Islamism and traditionalism. ${ }^{35}$

However, with the efforts of the modern scholars of Islam, better understanding of Islamic ideologies will be spread all over the United States of America and the American government and the opinion leaders will work on how the labeling and causes for islamophobia will be refined, clarified, and modified for better results.

\section{Bibliography}

32 Nancy Foner and Richard Alba, "Immigrant Religion in the Us and Western Europe: Bridge or Barrier to Inclusion?," International Migration Review 42, no. 2 (2008): 360-92.

33 Yvonne Yazbeck Haddad, A Century of Islam in America.

34 Paul Barrett and Paul M Barrett, American Islam: The Struggle for the Soul of a Religion (N.p.: Macmillan, 2007).

35 William E. Shepard, "Islam and Ideology: Towards a Typology, "International Journal of Middle East Studies 19, no. 3 (1987): 307-36. 
Al-Ammar, Bensaid K, Ismaiel H Ahmed, and Mohamad Sahari Nordin. "Moral Character of Muslim Personality: Scale Validation," Journal of Education and Practice 3, no. 16 (2012): 118-28.

Bandura, Albert. "Social Foundations of Thought and Action." The health Psychology Reader (2002): 94-106.

Barrett, Paul, and Paul M Barrett. American Islam: The Struggle for the Soul of a Religion. N.p.: Macmillan, 2007.

Beekun, Rafik I. "Character Centered Leadership: Muhammad (P) as an Ethical Role Model for CEOs." Journal of Management Development 31, no. 10 (2012): 1003-10020.

Bensaid, Benaouda, and Salah Machouche, "Muslim Morality as Foundation for Social Harmony," Journal of Al-Tamaddun 14, no. 2 (2019).

Clarke, Monet. "Race, Partisanship, and the Voting Rights Act (Vra): African-Americans in Texas from Reconstruction to the Republican Redistricting of 2004." Tex. J. on CL \& CR 10 (2004): 223.

Cochran, Kathryn F, James A DeRuiter, and Richard A King. "Pedagogical Content Knowing: An Integrative Model for Teacher Preparation." Journal of Teacher Education 44, no. 4 (1993): 263-272.

Darroch, Jacqueline E, David J Landry and Susheela Singh. "Changing Emphases in Sexuality Education in Us Public Secondary Schools, 1988-1999." Family Planning Perspectives (2000): 204-11.

Ebrahimji Maria M, and Zahra T Suratwala. "I Speak for Myself: American Women on Being Muslim," Ashland, OR: White Cloud Press (2011).

Foner, Nancy, and Richard Alba. "Immigrant Religion in the Us and Western Europe: Bridge or Barrier to Inclusion?." International Migration Review 42, no. 2 (2008): 360-92.

Garah, Wafa El. et al. "Character Centered Leadership: Muhammad (P) as an Ethical Role Model for CEOs." Journal of Management Development (2012).

Haddad, Yvonne Yazbeck. A Century of Islam in America. Washington, DC: American Institute for Islamic Affairs, 1986. 
Kaymakcan, Recep. "Religious Education Culture in Modern Turkey," in International Handbook of the Religious, Moral and Spiritual Dimensions in Education (Springer, 2009): 449-60.

Leirvik, Oddbjørn. Images of Jesus Christ in Islam. N.p.: Bloomsbury Publishing, 2010.

MacFarquhar, Neil. "For Muslim Students, a Debate on Inclusion." New York Times 21 (2008).

McEwan, Patrick J and Martin Carnoy. "The Effectiveness and Efficiency of Private Schools in Chile's Voucher System." Educational Evaluation and Policy Analysis 22, no. 3 (2000): 213-239.

Mizia, Robert Louis. "Prejudice and Educational Choice: 75th Anniversary of Pierce V. Society of Sisters." Momentum 31, no.2 (2000): 17-19.

O'Neil, Robert M. Classrooms in the Crossfire: The Rights and Interests of Students, Parents, Teachers, Administrators, Librarians, and the Community. N.p.: Indiana University Press, 1981).

Pajares, M Frank. "Teachers' Beliefs and Educational Research: Cleaning up a Messy Construct." Review of Educational Research 62, no. 3 (1992): 307-32.

Pala, Aynur. "The Need for Character Education." International Journal of Social Sciences and Humanity Studies 3, no. 2 (2011): 23-32.

Salomone, Rosemary C. Visions of Schooling: Conscience, Community, and Common Education. N.p.: Yale University Press, 2002.

Shepard, William E. "Islam and Ideology: Towards a Typology." International Journal of Middle East Studies 19, no. 3 (1987): 307-36.

Stinchcomb, Jeanne B, Gordon Bazemore and Nancy Riestenberg. "Beyond Zero Tolerance: Restoring Justice in Secondary Schools." Youth Violence and Juvenile Justice 4, no. 2 (2006): 123-47.

Syed Jawad and Beverly Dawn Metcalfe. "Guest Editors' Introduction: In Pursuit of Islamic Akhlaq of Business and Development." Journal of Business Ethics 129, no. 4 (2015): 763-767. 
Turker, Duygu. "Islamic Roots of Corporate Social Responsibility." Cultural Roots of Sustainable Management, Springer 2016. 133-144.

Tyack, David, and Elizabeth Hansot, "Learning Together: A History of Coeducation in American Public Schools." Russell Sage Foundation (1992).

Woodhouse, Barbara Bennett. "A Public Role in the Private Family: The Parental Rights and Responsibilities Act and the Politics of Child Protection and Education," Ohio St. LJ 57 (1996): 393.

Yusuf, Hamza. "The Concept of Ihsan." Website Islamicity, www.islamicity.org/5761/the-concept-of-ihsan-by-hamzayusuf/, 2014. Islamic City .org. 06/12/2018 2018. 